\title{
Impact of agricultural management on bacterial laccase- encoding genes with possible implications for soil carbon storage in semi-arid Mediterranean olive farming
}

\author{
Beatriz Moreno $^{1}$, Emilio Benitez ${ }^{\text {Corresp. } 1}$ \\ ${ }^{1}$ Department of Environmental Protection, CSIC-Estacion Experimental del Zaidin (EEZ), Granada, Spain \\ Corresponding Author: Emilio Benitez \\ Email address: emilio.benitez@eez.csic.es
}

Background . In this work, we aimed to gain insights into the contribution of soil bacteria to carbon sequestration in Mediterranean habitats. In particular, we aimed to use bacterial laccase-encoding genes as molecular markers for soil organic $\mathrm{C}$ cycling. Using rainfed olive farming as an experimental model, we determined the stability and accumulation levels of humic substances and applied these data to bacterial laccase-encoding gene expression and diversity in soils under four different agricultural management systems (bare soils under tillage/no tillage and vegetation cover under chemical/mechanical management).

Materials and Methods. Humic C ( $>10^{4} \mathrm{Da}$ ) was subjected to isoelectric focusing. The GC-MS method was used to analyze aromatic hydrocarbons. Real-Time PCR quantification and denaturing gradient gel electrophoresis ( DGGE) for functional bacterial laccase-like multicopper oxidase (LMCO)-encoding genes and transcripts were also carried out.

Results. Soils under spontaneous vegetation, eliminated in springtime using mechanical methods for morethan 30 years, showed the highest humic acid levels as well as the largest bacterial population rich in laccase genes and transcripts. The structure of the bacterial community based on LMCO genes also pointed to phylogenetic differences between these soils due to the impact of different management systems. Soils where herbicides were used to eliminate spontaneous vegetation once a year and those where pre-emergence herbicides resulted in bare soils clustered together for DNA-based DGGE analysis, which indicated a certain amount of microbial selection due to the application of herbicides. When LMCOencoding gene expression was studied, soils where cover vegetation was managed either with herbicides or with mechanical methods showed less than $10 \%$ similarity, suggesting that the type of weed management strategy used can impact weed community composition and consequently laccase substrates derived from vegetation decay.

Conclusions. We suggest that the low humic acid content retrieved in the herbicide-treated soils was mainly related to the type (due to vegetal cover specialization) and smaller quantity (due to lower vegetal biomass levels) of phenolic substrates for laccase enzymes involved in humification processes. We also found that spontaneous vegetal cover managed using mechanical methods could be the best option for achieving $\mathrm{C}$ stabilization in rainfed Mediterranean agroecosystems. 
1 IMPACT OF AGRICULTURAL MANAGEMENT ON BACTERIAL LACCASE-ENCODING GENES, WITH

2 POSSIBLE IMPLICATIONS FOR SOIL CARBON STORAGE IN SEMI-ARID MEDITERRANEAN OLIVE

3 FARMING

4

5 Beatriz Moreno and Emilio Benitez

6

7 Department of Environmental Protection, Estación Experimental del Zaidín (EEZ), CSIC,

8 Profesor Albareda 1, 18008 Granada, Spain

\section{Abstract}

Background. In this work, we aimed to gain insights into the contribution of soil bacteria to carbon sequestration in Mediterranean habitats. In particular, we aimed to use bacterial laccaseencoding genes as molecular markers for soil organic $\mathrm{C}$ cycling. Using rainfed olive farming as an experimental model, we determined the stability and accumulation levels of humic substances and applied these data to bacterial laccase-encoding gene expression and diversity in soils under four different agricultural management systems (bare soils under tillage/no tillage and vegetation cover under chemical/mechanical management).

Materials and Methods. Humic C $\left(>10^{4} \mathrm{Da}\right)$ was subjected to isoelectric focusing. The GC-MS method was used to analyze aromatic hydrocarbons. Real-Time PCR quantification and denaturing gradient gel electrophoresis (DGGE) for functional bacterial laccase-like multicopper oxidase (LMCO)-encoding genes and transcripts were also carried out. 
23 Results. Soils under spontaneous vegetation, eliminated in springtime using mechanical methods

24 for more than 30 years, showed the highest humic acid levels as well as the largest bacterial

25 population rich in laccase genes and transcripts. The structure of the bacterial community based

26 on LMCO genes also pointed to phylogenetic differences between these soils due to the impact

27 of different management systems. Soils where herbicides were used to eliminate spontaneous

28 vegetation once a year and those where pre-emergence herbicides resulted in bare soils clustered

29 together for DNA-based DGGE analysis, which indicated a certain amount of microbial selection

30 due to the application of herbicides. When LMCO-encoding gene expression was studied, soils

31 where cover vegetation was managed either with herbicides or with mechanical methods showed

32 less than $10 \%$ similarity, suggesting that the type of weed management strategy used can impact

33 weed community composition and consequently laccase substrates derived from vegetation

34 decay.

35 Conclusions. We suggest that the low humic acid content retrieved in the herbicide-treated soils

36 was mainly related to the type (due to vegetal cover specialization) and smaller quantity (due to

37 lower vegetal biomass levels) of phenolic substrates for laccase enzymes involved in

38 humification processes. We also found that spontaneous vegetal cover managed using

39 mechanical methods could be the best option for achieving $\mathrm{C}$ stabilization in rainfed

40 Mediterranean agroecosystems.

\section{INTRODUCTION}

44 Due to their importance for human welfare, ecosystem services have, in recent years, been 45 attracting increasing attention in the scientific literature. Although, traditionally, agroecosystems 
46 have been primarily regarded as service providers, their contribution to other types of ecosystem

47 services have recently been seen as equally crucial (MEA, 2005). Apart from providing food,

48 forage and bioenergy, agricultural ecosystem services have other benefits such as water and

49 climate system regulation, soil fertility and C sequestration (Chen et al., 2016). The latter

50 involves the removal of $\mathrm{C}$ from the atmosphere and its storage in soils through physical and

51 biological processes. As land-based biological C-mitigation strategies are regarded as important

52 and viable pathways to climate stabilization (Canadell \& Schulze, 2014), it is crucial to evaluate

53 the effects of land-use changes on ecosystem functions. However, in semi-arid climates,

54 agricultural soils are particularly vulnerable due to adverse environmental conditions and

55 centuries-old farming systems (Metzger et al., 2006).

56 One of the principal agroecosystems in semi-arid Mediterranean areas is that used for perennial

57 olive-orchard cropping. Olive is the most extensively cultivated fruit crop in the world, with

58 more than 10 million hectares under cultivation in 2013 (FAOSTAT, 2015). Its economic and

59 social importance is enormous, as reflected in the increasing per capita consumption of olive oil

60 around the world. However, olive growing also has a considerable ecological impact in the

61 Mediterranean region, where olive orchards constitute a fundamental part of the landscape.

62 Nevertheless, these agroecosystems are particularly exposed to degradation because of low soil

63 organic C (SOC) content.

64 The possibility of increasing the C-storage capacity of soils, with no significant reduction in

65 yields, through the use of an appropriate soil management system, has been widely discussed

66 (Scholes, Palm \& Hickman, 2014). A recent meta-analysis concluded that the most appropriate

67 strategy for maximizing SOC levels in the Mediterranean region is to combine organic inputs

68 with reduced tillage management (Aguilera et al., 2013). However, in rainfed olive farming, 
69 SOC is mainly dependent on plant-derived C-breakdown (Castro et al., 2008; Moreno et al.,

70 2009). SOC decomposition is generally thought to be regulated by biological and environmental

conditions (Schmidt et al., 2011). Litter provides the carbon that supports microbial activity, returns part of the $\mathrm{C}$ to the atmosphere and stores the rest in the form of humic substances, a highly stable organic fraction considered to be the true agent responsible for soil C-sequestration mechanisms (Miralles et al., 2014). There is overwhelming evidence which shows that C storage in soils is mainly limited by the incorporation of new $\mathrm{C}$ rather than by the decomposition of existing $\mathrm{C}$ and also shows the critical role played by the soil microbial community in these processes (Lange et al., 2015). Thus, the microbial degradation of plant-waste lignin has been recognized as a C turnover bottleneck in soil (Theuerl \& Buscot, 2010; Torres et al., 2014). The microbial breakdown of lignin has been well characterized, as have the enzymes involved, including laccase, lignin peroxidase and manganese peroxidase. However, the capacity to degrade lignin varies. By comparing the three classes of enzymes, Chen et al. (2011) have shown that laccases exhibit the most abundant aromatic-aromatic molecular interactions as well as the highest binding affinity. Laccases, generally laccase-like multicopper oxidases (LMCOs), whose kinetics have been widely studied, are probably the most common class of ligninolytic enzymes in soil. Although they have traditionally been regarded as fungal enzymes, there is mounting evidence which shows that bacterial LMCOs make a major contribution to lignin degradation and SOC turnover (Alexandre \& Zhulin, 2000; Sinsabaug, 2010). Laccase-encoding genes have been successfully used in recent studies as molecular markers for SOC cycling under many different environmental conditions and demonstrate the known potential of bacteria to degrade lignin (Baldrian \& López-Mondéjar, 2014). However, more studies are needed to elucidate the controversial role played by bacteria in soil C cycling (Kellner et al., 2008). 
92 In this study, we identify the management practices which best help to increase SOC stocks in

93 semi-arid agriculture in order to gain an insight into the contribution of soil bacteria to carbon

94 sequestration in Mediterranean habitats. Using rain-fed olive farming as an experimental model,

95 we thus determined the stability and accumulation levels of humic substances and then related

96 these data to bacteria laccase-encoding gene expression and diversity levels in soils under four

97 different agricultural management systems.

MATERIALS AND METHODS

100

\section{Experimental design}

102

103 The main characteristics of the experiment and soils are described in Castro et al. (2008) and

104 Moreno et al. (2009). The study was conducted in Jaen in south-east Spain (Supplemental Files: sampling locations), with a random block experimental plot design consisting of four treatments and four replicates. Each plot consisted of 16 olive trees, with the central four monitored trees surrounded by guard rows. The experiment, involving bare vs. covered soils, was begun in 1976 and was carried out over a period of 30 years. Samples were collected in May 2011. The treatments tested were:

110 Tillage (T): Bare soils where weeds were eliminated by 3-4 annual passes with a disk harrow (at

$11130 \mathrm{~cm}$ deep) and/or a cultivator in spring, followed by a tine harrow in summer.

112 Non-tillage and no-cover (NC): Bare soils where weeds were eliminated by applying the pre113 emergence herbicide oxyfluorfen in autumn. In the spring, glyphosate was applied locally. 
114 Cover crop + herbicides $(\mathrm{CH})$ : Covered soils where weeds were left to grow each year to be

115 eliminated in spring with herbicide glyphosate.

116 Cover crops + mower $(\mathrm{CM})$ : Covered soils where weeds were left to grow each year to be

117 eliminated in spring with various passes of a chain mower.

118 Two samples were collected from the centre of each plot, using a modified soil-sample ring kit

119 (Eijkelkamp), which consists of a $20 \mathrm{~cm}$-deep sampling cylinder specifically manufactured for

120 this purpose, and then bulked. To isolate the nucleic acids, subsamples of fresh soil were

121 immediately frozen in liquid nitrogen. The samples were stored at $-80^{\circ} \mathrm{C}$ until molecular analyses

122 were carried out.

123

124 Humic substances and isoelectric focusing

125

126 In this study, humic $\mathrm{C}$ was measured in sodium pyrophosphate extract ( $\mathrm{pH} 7.1)$, a good 127 extractant of humic compounds (Nannipieri et al., 1974; Piccolo et al., 1998). Humic substances

128

129

130

131

132

133

134

135

136 were extracted at $37^{\circ} \mathrm{C}$ for $24 \mathrm{~h}$ under shaking, using $\mathrm{Na}_{2} \mathrm{P}_{4} \mathrm{O}_{7}(0.1 \mathrm{M}, \mathrm{pH} 7.1)$ in a $1: 10 \mathrm{w} / \mathrm{v}$ dry soil:extract ratio (Ceccanti et al., 1978). The suspension was then centrifuged at $12,400 \mathrm{~g}$ and filtered through a $0.22 \mu \mathrm{m}$ Millipore membrane. The $>10^{4}$ Da humic-derived fraction was obtained through ultrafiltration on the AMICON PM10 membrane of the extract. The C content of humic $\mathrm{C}\left(>10^{4} \mathrm{Da}\right)$ was determined by acid digestion with $0.17 \mathrm{M} \mathrm{K}_{2} \mathrm{Cr}_{2} \mathrm{O}_{7}$ and concentrated (97\%) $\mathrm{H}_{2} \mathrm{SO}_{4}$ at $140{ }^{\circ} \mathrm{C}$ for $2 \mathrm{~h}$. A spectrophotometric method was used to quantify the $\mathrm{Cr}^{3+}$ produced by the reduction of $\mathrm{Cr}^{6+}(\lambda=590 \mathrm{~nm}$; Yeomans \& Bremner, 1988).

Isoelectric focusing (IEF) of humic $\mathrm{C}\left(>10^{4} \mathrm{Da}\right)$ was carried out in cylindrical gel rods $(0.5 \times 8$ $\mathrm{cm})$ containing polyacrylamide gel $(5 \% \mathrm{w} / \mathrm{v})$ and carrier ampholines in the $\mathrm{pH} 4-6$ range (Bio- 
137 Rad Laboratories, Richmond, CA, USA) at a final concentration of 2\% (Ceccanti et al., 1986; 138 1989). $\mathrm{N}, \mathrm{N}, \mathrm{N}^{\prime}, \mathrm{N}^{\prime}$-Tetramethyl-1,2-diaminomethane and ammoniumperoxy-disulfate were also 139 added in a gel solution at $0.03 \%$. At the top of the gel rod (cathode), $100 \mu$ l of humic $\mathrm{C}\left(>10^{4}\right.$ $140 \mathrm{Da})$ at $4.4 \%$ of glycerine were applied. A small amount $(5 \mu \mathrm{l})$ of glycerine at $2.2 \%$ was added to 141 the top of the sample to avoid mixing with the cathodic solution $(\mathrm{NaOH} 0.02 \mathrm{~N}) ; 0.01 \mathrm{M} \mathrm{H}_{3} \mathrm{PO}_{4}$ 142 was used for the anodic cell. A pre-run of $1 \mathrm{~h}$ at the same current intensity and voltage used for 143 the samples run was carried out for each gel tube (1.5 mA for each tube, $100-800 \mathrm{~V})$; the 144 samples run was then carried out for $2 \mathrm{~h}$ or longer until stable IEF banding was reached. The 145 electrophoretic bands were scanned using a Bio-Rad GS 80 densitometer, giving a typical IEF 146 profile for each soil investigated. The IEF peak area was determined for each soil IEF profile, 147 assuming as $100 \%$ the area under the entire IEF profiles (representative of the total loaded C). 148 Gel pH was measured at $0.5 \mathrm{~cm}$ intervals with an Orion microprocessor (model 901, Orion 149 research) connected to a microelectrode gel-pHiler (Bio-Rad Laboratories, Richmond, CA, 150 USA).

\section{Aromatic Hydrocarbons}

Aromatic hydrocarbons were extracted ultrasonically from $5 \mathrm{~g}$ of freeze-dried soils using $10 \mathrm{ml}$ of hexane/acetone $(1: 1 \mathrm{v} / \mathrm{v}) .50 \mu \mathrm{l}$ of $\mathrm{C} 3$-naphthalene in dichloromethane was added as a GC internal standard. After centrifugation and concentration, the solvent was dried by passing it over anhydrous sodium sulfate. The aromatic hydrocarbons were analyzed using a large volume injection-gas chromatography mass spectrometry (LVI-GC-MS) method. GC analyses were conducted on a Varian 450-GC fitted with a 1079 injector in split/splitless mode, a CTC 
160 Analytics CombiPal refrigerated autosampler and a Varian 240 Ion Trap as a mass spectrometer

161 detector. The samples were injected in large volume mode using the 1079 PTV injector. $10 \mu 1$

162 were injected with the split open (split ratio of $1 / 100$ ) for $0.5 \mathrm{~min}$ to purge the solvent, the split

163 was then closed for 3 min, with the injector temperature ramped up, and the split was finally

164 opened again (split ratio of 1/50). The injector temperature started at $60{ }^{\circ} \mathrm{C}$ for 0.5 min and then

165 ramped up by $100{ }^{\circ} \mathrm{C} / \mathrm{min}$ to $280{ }^{\circ} \mathrm{C}$ for $8 \mathrm{~min}$. A Thermo TG-5SILMS fused silica capillary

166 column $(30 \mathrm{~m} \times 0.25 \mathrm{~mm} \times 0.25 \mu \mathrm{m})$ was used. Temperature ramp: $70{ }^{\circ} \mathrm{C}(3.5 \mathrm{~min})>>25{ }^{\circ} \mathrm{C} / \mathrm{min}$

167 to $180{ }^{\circ} \mathrm{C}(10 \mathrm{~min})>>4{ }^{\circ} \mathrm{C} / \mathrm{min}$ to $300{ }^{\circ} \mathrm{C}(13 \mathrm{~min}) .10 \mu \mathrm{l}$ of the extracts were injected according

168 to the LVI method. The carrier gas was $\mathrm{He}$ at $0.9 \mathrm{ml} \mathrm{min}^{-1}$. Electron-impact ionization and

169 detection in full scan (m/z 50 to 500) mode were used. Structural and quantitative information

170 were obtained by comparing the mass spectra and retention times of the samples and standards

171 with the aid of MS Workstation 6.9.1 software.

172

173 Nucleic acid isolation from soils and cDNA synthesis

175 For each soil-sample replicate, the total community-DNA was separately extracted from four $1 \mathrm{~g}$ subsamples using the bead-beating method by following the manufacturer's instructions for the MoBioUltraClean Soil DNA Isolation kit (MoBio laboratories, Solana Beach, CA, USA). The extracts were pooled and further concentrated at $35^{\circ} \mathrm{C}$ to a final volume of $20 \mu \mathrm{l}$ using a Savant Speedvac ${ }^{\circledR}$ concentrator.

Total RNA was extracted from four $2 \mathrm{~g}$ subsamples of each replicate following the manufacturer's instructions for the MoBio RNA PowerSoil Total RNA Isolation kit (MoBio laboratories, Solana Beach, CA, USA). To remove residual DNA, DNase I enzyme was added 
183 using the RNase-Free DNase Set (Roche Applied Science, Penzberg, Germany) following the 184 manufacturer's instructions. The extracts were pooled and further concentrated at $35{ }^{\circ} \mathrm{C}$ to a final 185 volume of $80 \mu \mathrm{l}$ using a Savant Speedvac $\AA$ concentrator. The cDNA was synthesized from 1-2 $186 \mu \mathrm{g}$ of total DNase-treated RNA using the Transcriptor High Fidelity cDNA Synthesis Kit 187 according to the manufacturer's instructions (Roche Applied Science, Penzberg, Germany). The 188 synthesis reaction was carried out at $50{ }^{\circ} \mathrm{C}$ for $30 \mathrm{~min}$. The concentration and quality of the final 189 DNA/RNA/cDNA samples were checked with the aid of a Nanodrop ${ }^{\circledR}$ ND-100 spectrometer 190 (Nanodrop Technologies, Wilmington, DE, USA).

191

Quantitative real-time PCR assays

Real-time PCR quantification of DNA/cDNA for bacterial functional LMCO-encoding genes and transcripts was based on amplification with primers Cu1AF (5'-ACM WCB GTY CAY TGG CAY GG-3') and Cu2R (5'-G RCT GTG GTA CCA GAA NGT NCC-3’), designed by Kellner et al. (2008). Agarose-gel electrophoresis was carried out to confirm the specific PCR product, resulting in a single band of the expected size (approximately $144 \mathrm{bp}$ ), with primer sequences excluded. To determine whether the primers were specific for amplification and detection of bacterial LMCO genes and transcripts of the soils tested, an LMCO gene-clone library was established after PCR of soil DNA samples. A total of 46 sequences were analysed: 38 showed homology to LMCO-genes, 6 showed homology to the cloning vector, 2 were badly sequenced and 1 did not show homology to the LMCO-genes (Supplemental Files: homology). cDNA, $10.5 \mu 1$ 2x iQ SYBR Green Supermix (Bio-Rad, Munich, Germany) and $400 \mathrm{nM}$ of each 
206 primer. For each DNA/cDNA extracted, real-time PCR experiments were carried out three times, 207 with the threshold cycle $(\mathrm{Ct})$ determined in triplicate. The real-time PCR program consisted of 2 $208 \mathrm{~min}$ at $50{ }^{\circ} \mathrm{C}$ for carryover prevention, $5 \mathrm{~min}$ at $94{ }^{\circ} \mathrm{C}$ for enzyme activation, followed by 5 209 cycles consisting of $94{ }^{\circ} \mathrm{C}$ for $15 \mathrm{~s}, 57-54{ }^{\circ} \mathrm{C}$ for $15 \mathrm{~s}$, while decreasing the temperature by 0.5 $210{ }^{\circ} \mathrm{C}$ in every cycle, $72{ }^{\circ} \mathrm{C}$ for $30 \mathrm{~s}$, and 30 cycles consisting of $94{ }^{\circ} \mathrm{C}$ for $15 \mathrm{~s}, 54{ }^{\circ} \mathrm{C}$ for $15 \mathrm{~s}$ and $21172{ }^{\circ} \mathrm{C}$ for $30 \mathrm{~s}$; the fluorescence signal was measured at the $72{ }^{\circ} \mathrm{C}$ step for both DNA and cDNA. 212 The final step lasted $7 \mathrm{~min}$ at $72{ }^{\circ} \mathrm{C}$. The PCR amplification procedure was checked using a heat 213 dissociation protocol (from $70{ }^{\circ} \mathrm{C}$ to $100{ }^{\circ} \mathrm{C}$ ) following the final PCR cycle. The LMCO214 encoding gene copy number was quantified on an iQ5 thermocycler using iQ5-Cycler software 215 (Bio-Rad, Munich, Germany).

216 A standard curve was generated by using a recombinant plasmid containing one copy of the 217 LMCO gene from soil bacteria. The curves were drawn according to the method described by 218 Moreno et al. (2013). The relationship between the threshold cycle (Ct) and target-gene copy 219 number and the copy numbers of the real-time standard was calculated as described by Qian et al. $(2007)$ using the formula $\mathrm{Ct}=-3.089 \times \log _{10}(\mathrm{LMCO})+30.254, \mathrm{R}^{2}=0.984$. Target molecules 221 were linear from $10^{4}$ to $10^{9}$ copies.

222 The potential presence of qPCR inhibitors was tested by mixing $1 \mu$ (4-8 ng) of soils DNA extracts or $1 \mu \mathrm{l}(50-350 \mathrm{ng})$ of soils cDNA extracts with a known amount of recombinant plasmid DNA (pCR®2.1, Invitrogen, Carlsbad, CA, USA) with the appropriate primers. Controls, where DNA and cDNA templates were replaced by filter-sterilized milliQ water, were carried out simultaneously. Ct values did not significantly differ between the DNA/cDNA extracts and the controls. 
231 The community structure of bacterial LMCO-encoding genes and transcripts was studied by

232 DGGE analysis, for which Cu1AF-DGGE and $\mathrm{Cu} 2 \mathrm{R}$ primers were used. Primer Cu1AF-DGGE 233 contained the same sequence as Cu1AF but with an additional 40-nucleotide GC-rich sequence 234 (GC clamp) at the 5' end of the primer.

235

236

238

239

240

241

242

243

244

245

246

247

248

249

250

251

DGGE analyses were conducted using $550 \mathrm{ng}$ of the final PCR product loaded onto a 45-60\% urea-formamide-polyacrylamide gel. An INGENYphorU System (Ingeny International BV, The Netherlands) was run at $200 \mathrm{~V}$ for $10 \mathrm{~min}$ followed by $75 \mathrm{~V}$ for $18 \mathrm{~h}$ at $58^{\circ} \mathrm{C}$ in order to separate the fragments. Gels were silver stained with the Bio-Rad Silver Stain according to the standard DNA-staining protocol and photographed under UV light $(\lambda=254 \mathrm{~nm})$ using a UVItec Gel Documentation system (UVItec Limited, Cambridge, UK).

\section{Data analyses}

Results are the means of 12 replicates (three per plot) for chemical analyses. With regard to nucleic acids, 4 extractions of each sample were carried out and then grouped together to obtain a single sample per plot. The results were subjected to a factorial analysis of variance (ANOVA) using the STATISTICA software program (StatSoft Inc., Tulsa, OK, USA). The post hoc Tukey HSD test in a one-way ANOVA was used. P-values of under 0.05 were considered to be evidence of statistical significance.

Band patterns in different DGGE lanes were compared with the aid of UVImap Analysis software (UVItec Limited, Cambridge, UK). DGGE banding data were used to estimate the Raup 
252 and Crick probability-based index of similarity (SRC) (1979). Raup and Crick's probability

253 method was used to determine whether similarities within and between samples were stronger or

254 weaker than the randomized prediction. For this purpose, band-matching data were stored as a 255 binary matrix and analyzed using the aforementioned probability-based index. The SRC index 256 measures the probability of the randomized similarity being greater than or equal to the similarity 257 actually observed; SRC values of over 0.95 or under 0.05 indicate similarity or dissimilarity, 258 respectively, which are not random assortments of the same species (bands or OTUs) (Rowan et 259 al., 2003). SRC and cluster analyses were carried out using the PAST (Paleontological Statistics) 260 software program version 1.82b (Hammer, Harper \& Ryan, 2001).

\section{RESULTS}

\section{Organic Carbon Fractions}

We found that the high-molecular-weight $\left(\mathrm{C}>10^{4} \mathrm{Da}\right)$ humic acid (HA) fractions behaved in a significantly different way from total SOC (Table 1). HA levels were much higher in CM, comparable in $\mathrm{CH}$ and $\mathrm{NC}$ and considerably lower in the $\mathrm{T}$ treatment. Figure 1 shows the IEF patterns of HAs. All the treatments showed the highest optical-density values (IEF peaks) in the pH range 4.5-4.2 (band 1 and band 2).

Aromatic hydrocarbons 
274 The results of the analysis of major aromatic hydrocarbons are shown in Table 2 . Three main 275 polycyclic aromatic hydrocarbons were detected in soil samples. 2,6-diisopropylnaphthalene $276(\mathrm{~m} / z=239+199)$ was found to be present in all soils, although values were close to the detection 277 limit in the CM treatment. The levels of pp-DDA, a polar metabolite of DDT also found in all 278 soils, were significantly higher in the NC treatment. The third compound, present only in the NC 279 and $\mathrm{CH}$ soils, was a mixture of four aromatic hydrocarbons $(\mathrm{m} / \mathrm{z}=265+266+331)$, whose mass 280 spectra did not match any compounds in the library. To gain a better understanding of this 281 mixture, its mass spectra are shown as supplementary material (Supplemental Files: mass 282 spectra). The data appear to suggest that the $\mathrm{C}$ and $\mathrm{D}$ compounds, containing an odd number of $283 \mathrm{~N}$ atoms, are dimers of $\mathrm{A}$ and $\mathrm{B}$, respectively.

\section{Real-time PCR assays and LMCO gene expression}

Table 3 shows LMCO-encoding gene and transcript-copy numbers in the four treatments, both of which were much higher in CM soil and comparable in the other treatments.

\section{LMCO-encoding gene and transcript diversity}

Figure 2 shows the DNA- and RNA-based DGGE dendrograms generated by Raup and Crick cluster analyses (see Supplemental Files: DGGE bands). The SRC values, obtained by comparing the four treatments, are also summarized in Figure 2. With respect to LMCOencoding genes (Fig. 2a), T and NC soils differed significantly $(\mathrm{SRC}<0.05)$. For the other pairs of DNA-DGGE profiles compared, the similarity was no greater than that the random prediction 
297 (0.95 > SRC > 0.05). However, SRC values comparing CM and the other treatments were very 298 close to the dissimilarity boundary (SRC $<0.05)$, as evidenced by the solitary cluster where these 299 soils were located.

300 When the LMCO transcripts were evaluated (Fig. 2b), T and NC soils clustered together, 301 showing a high degree of similarity $(\mathrm{SRC} \approx 1)$. $\mathrm{CH}$ and $\mathrm{CM}$ soils showed low similarity $(<10 \%)$. 302 After comparing CM with the other soils, the similarity was found to be no greater than that 303 randomly predicted $(0.95>\mathrm{SRC}>0.05)$.

\section{DISCUSSION}

In recent years, scientists have been discussing the relationship between agricultural management practices and soil-C sequestration. The long-term impact of several types of agricultural management on SOC dynamics has been extensively evaluated, some of which have been proposed as a means of offsetting anthropogenic $\mathrm{CO}_{2}$ emissions (Söderström et al., 2014). In particular, the advantage of including cover crops in cropping systems, as opposed to other management practices that increase SOC, has been highlighted (Poeplau \& Don, 2015).

Data on SOC dynamics obtained in our previous studies suggest that no absolute advantages in terms of $\mathrm{C}$ sequestration appear to be associated with any of the four types of agricultural management tested. A previous paper reported comparable amounts of aboveground vegetal biomass per year in $\mathrm{T}, \mathrm{CH}$ and $\mathrm{CM}$ treatments, as well as highly variable levels of annual biomass production which is typically found in semi-arid Mediterranean habitats, while leaves and root exudates from olive trees were the only $\mathrm{C}$ biomass input in the $\mathrm{NC}$ soil (see $\mathrm{C}$ vegetal

319 biomass in Table 1 from Castro et al., 2008). SOC, measured after 30 years of experiments, was 
320 shown to be significantly lower in $\mathrm{NC}$ as compared to the $\mathrm{T}$ and $\mathrm{CM}$ treatments, though similar

$321(\mathrm{p}<0.05)$ to the levels found in $\mathrm{CH}$ soils. However, no significant differences were observed

322 between the former and latter treatments (SOC in Table 1 in Cañizares, Moreno \& Benitez, 323 2012). Nevertheless, the outcomes for HAs have differed significantly, given that C324 sequestration mechanisms are primarily based on the stabilization of $\mathrm{C}>10^{4} \mathrm{Da}$ (Miralles et al., 325 2014). HA levels were much higher in CM soils, where spontaneous vegetation was allowed to 326 grow each year and then eliminated in spring using mechanical methods. The IEF profiles 327 confirm the stability levels of the humic substances isolated: larger quantities of organic C 328 compounds were found at higher $\mathrm{pH}$ values $(4.5-4.2)$ in the IEF gel, thus providing overwhelming evidence that the higher the isoelectric point, the more humified the organic 330 matter (Ceccanti \& Nannipieri, 1979; Govi, Ciavatta \& Gessa, 1994).

331 These results provide supporting evidence that reduced tillage and green manure incorporation 332 could represent the best option for $\mathrm{C}$ input and stabilization in the Mediterranean region (Alvaro333 Fuentes et al., 2009; Aguilera et al., 2013; Garcia-Ruiz \& Gomez-Muñoz, 2014; Garcia-Franco 334 et al., 2015). This has usually been explained by the greater physical-chemical protection of the 335 organic matter by microaggregates that this type of management provides. Tillage disrupts a 336 larger proportion of aggregates, thus releasing higher levels of organic $\mathrm{C}$ as compared to no337 tillage treatments (Six, Elliott \& Paustian, 1999), which could explain why the T treatment 338 exhibited the lowest HA levels. However, much of the current debate still revolves around SOC stabilization mechanisms, with existing evidence pointing to the synthesis of polyphenols as an essential step in HA formation. Polyphenols could be derived from lignin-degradation products or from microbial resynthesis, reflecting the importance of the specific type of vegetation and the

342 critical role played by microbial ligninolytic enzymes in the soil, specifically phenoloxidase, 
343 laccase and peroxidase activities (Stevenson, 1994). Laccases are probably the largest class of

344 ligninolytic enzymes in soil and perform different oxidative and polymerative functions. The 345 enzymes of the former group are mainly involved in lignin breakdown, while the latter are 346 chiefly involved in polymerizing soluble phenols, thereby contributing to humification 347 (Gianfreda, Xu \& Bollag, 1999). The data gathered in the present study suggest that there is a 348 relationship between the number and expression of bacterial LMCO genes on the one hand and 349 the quantity and stability of HAs on the other. Soils under vegetal cover managed by mechanical 350 methods, where the highest HA levels were retrieved after 30 years of experiments, showed the largest bacterial population rich in laccase genes. Also, the environmental conditions facilitated a corresponding higher level of gene expression in these soils as compared to other treatments. The structure of the bacterial community based on LMCO genes also points to a phylogenetic difference in $\mathrm{CM}$ soils due to the management system used. $\mathrm{CH}$ and $\mathrm{NC}$ soils clustered together in the DNA-based DGGE analysis, suggesting a certain amount of microbial selection due to the application of herbicides. With respect to LMCO-encoding gene expression, $\mathrm{CH}$ and $\mathrm{CM}$ soils showed low similarity $(<10 \%)$, indicating that the type of weed management strategy used can impact weed populations and consequently laccase substrates derived from vegetation decay. been highlighted following long-term applications of preemergence herbicides as compared to non-chemical weed control management (Sosnoskie, Herms \& Cardina, 2006; Barroso et al., 362 2015; Fracchiolla et al., 2015).

363 However, the results above did not provide confirmatory evidence concerning the role played by

364 bacterial laccase in HA formation. Laccase substrates are quite diverse and extracellular bacterial 365 laccase can oxidize other compounds such as dyes, pesticides and polycyclic aromatic 
366 hydrocarbons (Majeau, Brar \& Tyagi, 2010). Nevertheless, in this study, almost all predominant

367 aromatic hydrocarbon and herbicide metabolites were retrieved when herbicides were part of the

368 agricultural management system; neither the type nor amount correlated with LMCO gene

369 copies, transcript numbers or diversity.

370 Bringing together the above results, we found that management systems involving the

371 application of herbicides could influence bacterial laccase activity and diversity either directly

372 through their effect on soil microorganisms or indirectly through vegetal cover specialization.

373 The literature provides considerable evidence to show that different types of lignin phenols are

374 found in specific types of vegetation (Radosevich, Holt \& Ghersa, 1997; Caseley, Cussans \&

375 Atkin, 2013), although there is no consensus on the effects of herbicides on microbial

376 community structure and activity in soil (Jacobsen \& Hjelmsø, 2014). Many authors have

377 described the side-effects of glyphosate on microorganisms as of "little ecological significance"

378 (Wardle \& Parkinson, 1990), while others have contended that it has a considerable ecological

379 impact (Nannipieri et al., 2003; Zobiole et al., 2011). In this long-term experiment, the claim that

380 herbicides have no significant effect on soil bacteria after 30 years of herbicide applications is

381 supported by previous data; soils under vegetation cover showed similar bacterial biomass and

382 activity levels and characteristics whether spontaneous weeds were eliminated by mechanical or

383 by chemical methods (Cañizares, Moreno \& Benitez, 2012). However, apart from a different

384 plant community pattern, herbicides could produce a collateral effect on certain bacterial

385 activities related to the soil $\mathrm{C}$ cycle. Weed biomass and leaf/root exudates from olive trees were

386 the sole $\mathrm{C}$ biomass input (Moreno et al., 2013), while litter-derived C was incorporated into both

387 more and less chemically stable compounds. However, after 30 years of experiments, we

388 detected an unexpected lower humification rate in $\mathrm{CH}$ as compared to $\mathrm{CM}$ soils. After reviewing 
389 the history of $\mathrm{CH}$ soils, we found that the herbicides diquat and paraquat had been applied over

390 the years until their prohibition (Moreno et al., 2009) and were later replaced by glyphosate. On

391 the basis of their mode of action, bipyridylium herbicides act by inhibiting photosynthesis

392 (Dodge, 1971), while glyphosate inhibits the formation of phenolic precursors necessary for the

393 production of lignin (Franz, Mao \& Sikorski, 1997). We can thus assume that the lignin content

394 of weeds incorporated into the soil in both circumstances was lower or simply different from that

395 incorporated into the CM treatment, and it is also generally accepted that the synthesis of

396 polyphenols from lignin is a critical step in $\mathrm{C}$ stabilization. Moreover, $\mathrm{CH}$ soils, where

397 vegetation cover was eliminated once a year with herbicides, and NC soils, where weeds were

398 prevented from growing by the application of herbicides, presented comparable levels of HAs as

399 well as similar bacterial laccase gene-copy numbers, diversity and expression.

400

401 ConcLusions

402

403

404

A long-term experiment comparing four types of agricultural management was conducted in a semi-arid Mediterranean agroecosystem. After 30 years of experiments, we found comparable 405 stable levels of $\mathrm{C}$ in both non-tillage + no cover soils and soils under spontaneous vegetation 406 cover managed using chemical methods. We suggest that the lower humic acid content retrieved 407 in the herbicide-treated soils was mainly related to the type, due to vegetal cover specialization, 408 and smaller quantity, due to lower vegetal biomass levels, of phenolic substrates for laccase 409 enzymes involved in humification processes. We also conclude that spontaneous vegetation cover managed with mechanical methods is the best option to achieve $\mathrm{C}$ stabilization. 


\section{ACKNOWLEDGMENTS}

413

414 The chromatographic analyses were carried out at the Scientific Instrumentation Service,

415 Estación Experimental del Zaidín, CSIC, Granada, Spain. We wish to thank Serena Doni from

416 ISE-CNR (Pisa, Italy) for the IEF analyses. We would also like to thank David Nesbitt and

417 Michael O'Shea for editing and proofreading the latest English version of the manuscript.

418

419

REFERENCES

420

421

422

Aguilera, E., Lassaletta, L., Gattinger, A., Gimeno, B.S., 2013. Managing soil carbon for climate change mitigation and adaptation in Mediterranean cropping systems: a meta-analysis. Agriculture, Ecosystems and Environment 168, 25-36.

424

Alexandre, G., Zhulin, I.B., 2000. Laccases are widespread in bacteria. Trends in Biotechnology 425 $18,41-42$.

Alvaro-Fuentes, J., López, M.V., Arrúe, J.V., Moret, D., Paustian, K., 2009. Tillage and cropping effects on soil organic carbon in Mediterranean semiarid agroecosystems: Testing the Century model. Agriculture, Ecosystems and Environment 134, 211-217.

Ausec, L., Zakrzewski, M., Goesmann, A., Schlüter, A., Mandic-Mulec, I., 2011. Bioinformatic 6(10): e25724. doi:10.1371/journal.pone.0025724.

Baldrian, P., López-Mondéjar, R., 2014. Microbial genomics, transcriptomics and proteomics: 
435 Barroso, J., Miller, Z.J., Lehnhoff, E.A., Hatfield, P.G., Menalled, F.D., 2015. Impacts of 436 cropping system and management practices on the assembly of weed communities. Weed 437 Research 55, 1365-3180.

438 Canadell, J.G., Schulze, E.D., 2014. Global potential of biospheric carbon management for 439 climate mitigation. Nature Communications 5, Article number: 5282.

440 Cañizares, R., Moreno, B., Benitez, E., 2012. Bacterial $\beta$-glucosidase function and metabolic 441 activity depend on soil management in semiarid rainfed agriculture. Ecology and Evolution 2, $442 \quad 727-731$.

443 Caseley, J.C., Cussans, G.W., Atkin, R.K., 2013. Herbicide resistance in weeds and crops. 444 Oxford/Boston: Butterworth-Heineman.

445 Castro, J., Fernandez-Ondoño, E., Rodrıguez, C., Lallena, A.M., Sierra, M., Aguilar, J., 2008. 446 Effects of different olive-grove management systems on the organic carbon and nitrogen 447 content of the soil in Jaen (Spain). Soil \& Tillage Research 98, 56-67.

448 Ceccanti, B., Nannipieri, P., 1979. Concerning the reliability of the isoelectric focusing 449 technique to separate the soil humic substances. In: Frigerio, A., Renoz, L. (Eds.) Recent 450 Developments in Chromatography and Electrophoresis. Elsevier, Amsterdam, vol 10, pp 225451232.

452 Ceccanti, B., Nannipieri, P., Cervelli, S., Sequi, P., 1978. Fractionation of humus-urease 453 complexes. Soil Biology \& Biochemistry 10, 39-45.

454 Chen, M., Zeng, G., Tan, Z., Jiang, M., Li, H., Liu, L., Zhu, Y., Yu, Z., Wei, Z., Liu, Y., XieG., 455 2011. Understanding lignin-degrading reactions of ligninolytic enzymes: binding affinity and 456 interactional profile. PloS one 6(9), e25647, doi:10.1371/journal.pone.0025647. 
457 Chen M., Zeng, G., Zhang, J., Xu, P., Chen, A., Lu, L., 2015. Global Landscape of Total Organic

458 Carbon, Nitrogen and Phosphorus in Lake Water. Scientific Reports 5, Article number: $459 \quad$ 15043, doi:10.1038/srep15043.

460 Chen M., Qin, X., Zeng, G., Li, J., 2016. Impacts of human activity modes and climate on heavy 461 metal "spread" in groundwater are biased. Chemosphere 152, 439-445.

462 Dodge, A.D., 1971. The mode of action of the bipyridylium herbicides, paraquat and diquat. $463 \quad$ Endeavour 30, 130-135.

464 FAOSTAT, 2015. Food and Agriculture Organization of the United Nations Statistics division, 465 available at: http://faostat3.fao.org (last access: 28 May 2015).

466 Fracchiolla, M., Terzi, M., Frabboni,L., Caramia, D., Lasorella, C., De Giorgio, D., Montemurro, 467 P., Cazzato, E., 2015. Influence of different soil management practices on ground-flora 468 vegetation in an almond orchard. Renewable Agriculture and Food Systems, 9 pp, 469 doi:10.1017/S1742170515000241.

470 Franz, J.E., Mao, M.K., Sikorski, J.A., 1997. Glyphosate: a unique global herbicide. American 471 Chemical Society: Washington, DC.

472 Garcia-Franco, N., Albaladejo, J., Almagro, M., Martínez-Mena. M. 2015. Beneficial effects of 473 reduced tillage and green manure on soil aggregation and stabilization of organic carbon in a 474 Mediterranean agroecosystem. Soil \& Tillage Research 153, 66-75.

475 Garcia-Ruiz, R., Gomez-Muñoz, B., 2014. Potential contribution of natural plant of the 476 intercanoppy of fruity crops on carbon sequestration. In: $477 \quad$ http://www.redremedia.org/events/images/stories/ponencias/poster/suelo-

478 planta/45_garcia_roberto.pdf. 
479 Gianfreda, L., Xu, F., Bollag, J.M., 1999. Laccases: A Useful Group of Oxidoreductive $480 \quad$ Enzymes. Bioremediation Journal 3, 1-26.

481 Govi, M., Ciavatta, C., Gessa, C., 1994. Evaluation of the stability of the organic matter in 482 slurries,sludges and composts using humification parameters and isoelectric focusing. In: 483 Senesi, N., Miano, T.M. (Eds.) Humic substances in the global environment and implications 484 on human health. Elsevier Science, Amsterdam, pp 1311-1316.

485 Hammer, Ø., Harper, D.A.T., Ryan, P.D., 2001. Past: Paleontological statistics software package 486 for education and data analysis. Palaeontologia Electronica 4, 9 pp.

487 Jacobsen, C.S., Hjelmsø, M.H., 2014. Agricultural soils, pesticides and microbial diversity. 488 Current Opinion in Biotechnology 27, 15-20.

489 Kellner, H., Luis, P., Zimdars, B., Kiesel, B., Busco, F., 2008. Diversity of bacterial laccase-like 490 multicopper oxidase genes in forest and grassland Cambisol soil samples. Soil Biology \& $491 \quad$ Biochemistry 40, 638-648.

492 Lange, M., Eisenhauer, N., Sierra, C.A., Bessler, H.,Engels, C., Griffiths, R.I., Mellado-Vázquez, 493 P.G., Malik, A.A., Roy, J., Scheu, S., Steinbeiss, S., Thomson, B.C., Trumbore, S.E., 494 Gleixner, G., 2015. Plant diversity increases soil microbial activity and soil carbon storage. $495 \quad$ Nature Communications 6:6707, doi: 10.1038/ncomms7707.

496 Majeau, J.A., Brar, S.K., Tyagi, R.D., 2010. Laccases for removal of recalcitrant and emerging 497 pollutants. Bioresource Technology 101, 2331-2350.

498 MEA Millennium Ecosystem Assessment, 2005. Ecosystems and Human Well-Being: Synthesis. 499 Island Press, Washington, DC. 
500 Metzger, M.J., Rounsevell, M.D.A., Acosta-Michlik, L., Leemans, R., Schröter, D, 2006. The

501 vulnerability of ecosystem services to land use change. Agriculture, Ecosystems and

502 Environment 114, 69-85.

503 Miralles, I., Piedra-Buena, A., Almendros, G., González-Vila, F.J., González-Pérez, J.A., 2014.

504 Pyrolytic appraisal of the lignin signature in soil humic acids: Assessment of its usefulness as

505 carbon sequestration marker. Journal of Analytical and Applied Pyrolysis 113, 107-115.

506 Moreno, B., Cañizares, R., Nuñez, R., Benitez, E., 2013. Genetic diversity of bacterial $\beta$ -

507 glucosidase-encoding genes as a function of soil management. Biology and Fertility of Soils $508 \quad 49,735-745$.

509 Moreno, B., Garcia-Rodriguez, S., Cañizares, R., Castro, J, Benitez, E., 2009. Rainfed olive

510 farming in south-eastern Spain: Long-term effect of soil management on biological indicators

511 of soil quality. Agriculture, Ecosystems and Environment 131, 333-339.

512 Nannipieri, P., Ascher, J., Ceccherini, M.T., Landi, L., Pietramellara, G., Renella, G., 2003.

513 Microbial diversity and soil functions. European Journal of Soil Science 54, 655-670.

514 Nannipieri, P., Ceccanti, B., Cervelli, S., Sequi, P., 1974. Use of 0.1 M pyrophosphate to extract

515 urease from a podzol. Soil Biology \& Biochemistry 6, 359-362.

516 Piccolo, A., Conte, P., Scheunert, I., Paci, M., 1998. Atrazine interactions with soil humic 517 substances of different molecular structure. Journal of Environmental Quality 27, 1333-1724.

518 Poeplau, C., Don, A., 2015. Carbon sequestration in agricultural soils via cultivation of cover 519 crops-A meta-analysis. Agriculture, Ecosystems and Environment 200, 33-41.

520 Qian, H., Hu, B., Cao, D., Chen, W., Xu, X., Lu, Y., 2007. Bio-safety assessment of validamycin

521 formulation on bacterial and fungal biomass in soil monitored by real-time PCR. Bulletin of

522 Environmental Contamination and Toxicology 78, 239-244. 
523 Radosevich, S.R., Holt, J.S., Ghersa, C., 1997. Weed ecology: implications for management.

$524 \quad$ John Wiley \& Sons, New York.

525 Raup, D.M., Crick, R.E., 1979. Measurement of Faunal Similarity in Paleontology. Journal of 526 Paleontology 53, 1213-1227.

527 Rowan, A.K., Snape, J.R., Fearnside, D., Barer, M.R., Curtis, T.P., Head, I.M., 2003.

528 Composition and diversity of ammonia-oxidising bacterial communities in wastewater 529 treatment reactors of different design treating identical wastewater. FEMS Microbiology $530 \quad$ Ecology 43, 195-206.

531 Schmidt, M.W.I., Torn, M.S., Abiven, S., Dittmar, T., Guggenberger, G., Janssens, I.A., Kleber, 532 M., Kögel-Knabner, I., Lehmann, J., Manning, D.A.C., Nannipieri, P. Rasse, D.P., Weiner, S., 533 Trumbore, S.E., 2011. Persistence of soil organic matter as an ecosystem property. Nature $534 \quad 478,49-56$.

535 Scholes, R.J., Palm, C.A., Hickman, JE., 2014. Agriculture and climate change mitigation in the 536 developing world. CCAFS Working Paper No. 61. Copenhagen, Denmark: CGIAR Research 537 Program on Climate Change, Agriculture and Food Security (CCAFS).

538 Sinsabaug, R.L., 2010. Phenol oxidase, peroxidase and organic matter dynamics of soil. Soil 539 Biology \& Biochemistry 42, 391-404.

540 Six, J., Elliott, E.T., Paustian, K., 1999. Aggregate and soil organic matter dynamics under 541 conventional and no-tillage systems. Soil Science Society of America Journal 63, 1350-1358.

542 Söderström, B., Hedlund, K., Jackson, L.E., Kätterer, T., Lugato, E., Thomsen, I.K., Jørgensen, 543 H.B., 2014. What are the effects of agricultural management on soil organic carbon (SOC) 544 stocks? Environmental Evidence 3(2), doi:10.1186/2047-2382-3-2. 
545 Sosnoskie, L.M., Herms, C.P., Cardina, J., 2006. Weed seedbank community composition in a 546 35-yr-old tillage and rotation experiment. Weed Science 54, 263-273.

547 Stevenson, F.J., 1994. Humus chemistry. John Wiley \& Sons, New York.

548 Theuerl, S., Buscot, F., 2010. Laccases: toward disentangling their diversity and functions in 549 relation to soil organic matter cycling. Biology and Fertility of Soils 46, 215-225.

550 Torres, I.F., Bastida, F., Hernández, T., Bombach, P., Richnow, H.H., García, C., 2014. The role 551 of lignin and cellulose in the carbon-cycling of degraded soils under semiarid climate and 552 their relation to microbial biomass. Soil Biology \& Biochemistry 75,152-160.

553 Tveit, A., Schwacke, R., Svenning, M.M., Urich, T., 2013. Organic carbon transformations in 554 high-Arctic peat soils: key functions and microorganisms. The ISME Journal 7, 299-311.

555 Wardle, D.A., Parkinson, D., 1990. Effects of three herbicides on soil microbial biomass and 556 activity. Plant Science 122, 21-28.

557 Yeomans, J.C., Bremner, J.M., 1988. A rapid and precise method for routine determination of 558 organic carbon in soil. Communications in Soil Science Plant Analysis 19, 1467-1476.

559 Zobiole, L.H.S., Kremer, R.J., Oliveira, R.S., Constantin, J., 2011. Glyphosate affects micro560 organisms in rhizospheres of glyphosate-resistant soybeans. Journal of Applied Microbiology $561 \quad 110,118-127$. 


\section{Table $\mathbf{1}$ (on next page)}

Table 1

Table 1 - Organic carbon fractions for tillage (T), non-tillage and no-cover (NC), cover

vegetation + herbicides $(\mathrm{CH})$, and cover vegetation + mower $(\mathrm{CM})$ treatments (means $\pm \mathrm{SE}$ ).

For each parameter, significant differences are indicated by different letters $(P<0.05$, ANOVA, Tukey post-hoc). 


\begin{tabular}{|c|c|c|c|}
\hline & $\begin{array}{c}\text { C vegetal biomass } \\
\left(\mathrm{kg} \mathrm{ha}^{-1} \text { year }^{-1}\right)^{*}\end{array}$ & $\begin{array}{c}\text { SOC } \\
\left(\mathrm{g} \mathrm{kg}^{-1}\right)^{* *}\end{array}$ & $\begin{array}{c}\text { HAs }\left(\mathrm{C}>10^{4} \mathrm{Da}\right) \\
\left(\mathrm{mg} \mathrm{kg}^{-1}\right)\end{array}$ \\
\hline $\mathbf{T}$ & $3743 \mathrm{a}$ & $9.4 \pm 3.1 \mathrm{a}$ & $306 \pm 1.1 \mathrm{c}$ \\
\hline $\mathrm{NC}$ & ---- & $4.6 \pm 0.7 b$ & $390 \pm 2.9 b$ \\
\hline CH & $2617 \mathrm{a}$ & $6.8 \pm 3.2 \mathrm{ab}$ & $443 \pm 29 b$ \\
\hline CM & $4059 \mathrm{a}$ & $8.3 \pm 2.0 \mathrm{a}$ & $914 \pm 6.6 \mathrm{a}$ \\
\hline
\end{tabular}




\section{Table 2 (on next page)}

Table 2

Table 2 - Main aromatic hydrocarbons in tillage (T), non-tillage and no-cover (NC), cover vegetation + herbicides $(\mathrm{CH})$, and cover vegetation + mower $(\mathrm{CM})$ soils (means $\pm \mathrm{SE}$ ). For each parameter, significant differences are indicated by different letters $(P<0.05$, ANOVA, Tukey post-hoc). 


\begin{tabular}{lccc}
\hline & CAS 24157-81-1 & p,p-DDA & A+B+C+D \\
& $\mathbf{( 2 3 9 + 1 9 9 )}$ & & $\mathbf{( 2 6 5 + 2 6 6 + 3 3 1 )}$ \\
\hline $\mathbf{T}$ & $0.22 \pm 0.13 \mathrm{a}$ & $0.007 \pm 0.005 \mathrm{~b}$ & nd \\
$\mathbf{N C}$ & $0.19 \pm 0.05 \mathrm{a}$ & $0.021 \pm 0.001 \mathrm{a}$ & $0.36 \pm 0.05 \mathrm{a}$ \\
$\mathbf{C H}$ & $0.25 \pm 0.01 \mathrm{a}$ & $0.014 \pm 0.004 \mathrm{~b}$ & $0.22 \pm 0.05 \mathrm{a}$ \\
$\mathbf{C M}$ & $0.04 \pm 0.03 \mathrm{~b}$ & $0.011 \pm 0.001 \mathrm{~b}$ & $\mathrm{nd}$ \\
\hline
\end{tabular}




\section{Table 3(on next page)}

Table 3

Table 3 - LMCO-encoding gene and transcript copy numbers for tillage (T), non-tillage and nocover ( $\mathrm{NC})$, cover vegetation + herbicides $(\mathrm{CH})$, and cover vegetation + mower (CM) soils (means $\pm \mathrm{SE}$ ). For each parameter, significant differences are indicated by different letters ( $P$ $<0.05$, ANOVA, Tukey post-hoc). 


\begin{tabular}{lll}
\hline & LMCO gene copies g-1 $^{-1}$ & LMCO transcript copies g-1 \\
\hline $\mathbf{T}$ & $9.79 \times 10^{4} \pm 5.74 \times 10^{3} \mathrm{~b}$ & $1.34 \times 10^{3} \pm 3.16 \times 10^{2} \mathrm{~b}$ \\
$\mathbf{N C}$ & $1.02 \times 10^{5} \pm 8.64 \times 10^{3} \mathrm{~b}$ & $3.02 \times 10^{3} \pm 8.38 \times 10^{2} \mathrm{~b}$ \\
$\mathbf{C H}$ & $7.89 \times 10^{4} \pm 1.10 \times 10^{4} \mathrm{~b}$ & $6.67 \times 10^{3} \pm 3.21 \times 10^{3} \mathrm{~b}$ \\
$\mathbf{C M}$ & $5.71 \times 10^{5} \pm 4.03 \times 10^{4} \mathrm{a}$ & $4.12 \times 10^{4} \pm 4.86 \times 10^{3} \mathrm{a}$ \\
\end{tabular}

1 


\section{Figure 1 (on next page)}

\section{Figure 1}

Fig 1 - Isoelectric focusing profiles of HAs from tillage (T), non-tillage and no-cover (NC), cover vegetation + herbicides $(\mathrm{CH})$, and cover vegetation + mower $(\mathrm{CM})$ soils 


\section{IEF profile}

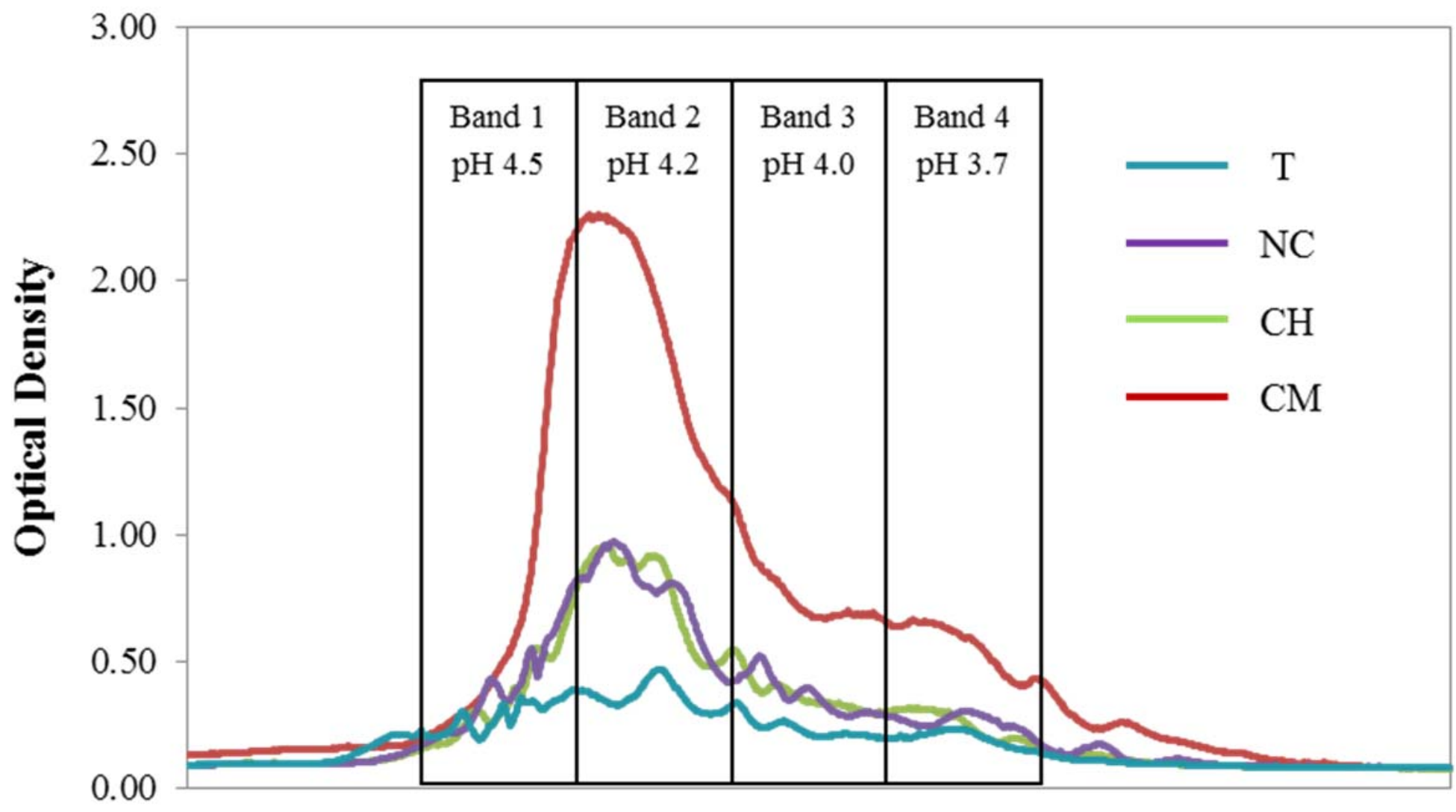




\section{Figure 2 (on next page)}

\section{Figure 2}

Fig 2 - Raup and Crick probability-based index of similarity cluster analyses and similarity values $\left(\mathrm{S}_{\mathrm{RC}}\right.$ ) between samples for profiles of DNA- $(\mathrm{a})$ and RNA- based DGGE analysis of LCMO-encoding genes (b) for tillage (T), non-tillage and no-cover (NC), cover vegetation + herbicides $(\mathrm{CH})$, and cover vegetation + mower $(\mathrm{CM})$ soils 
a)

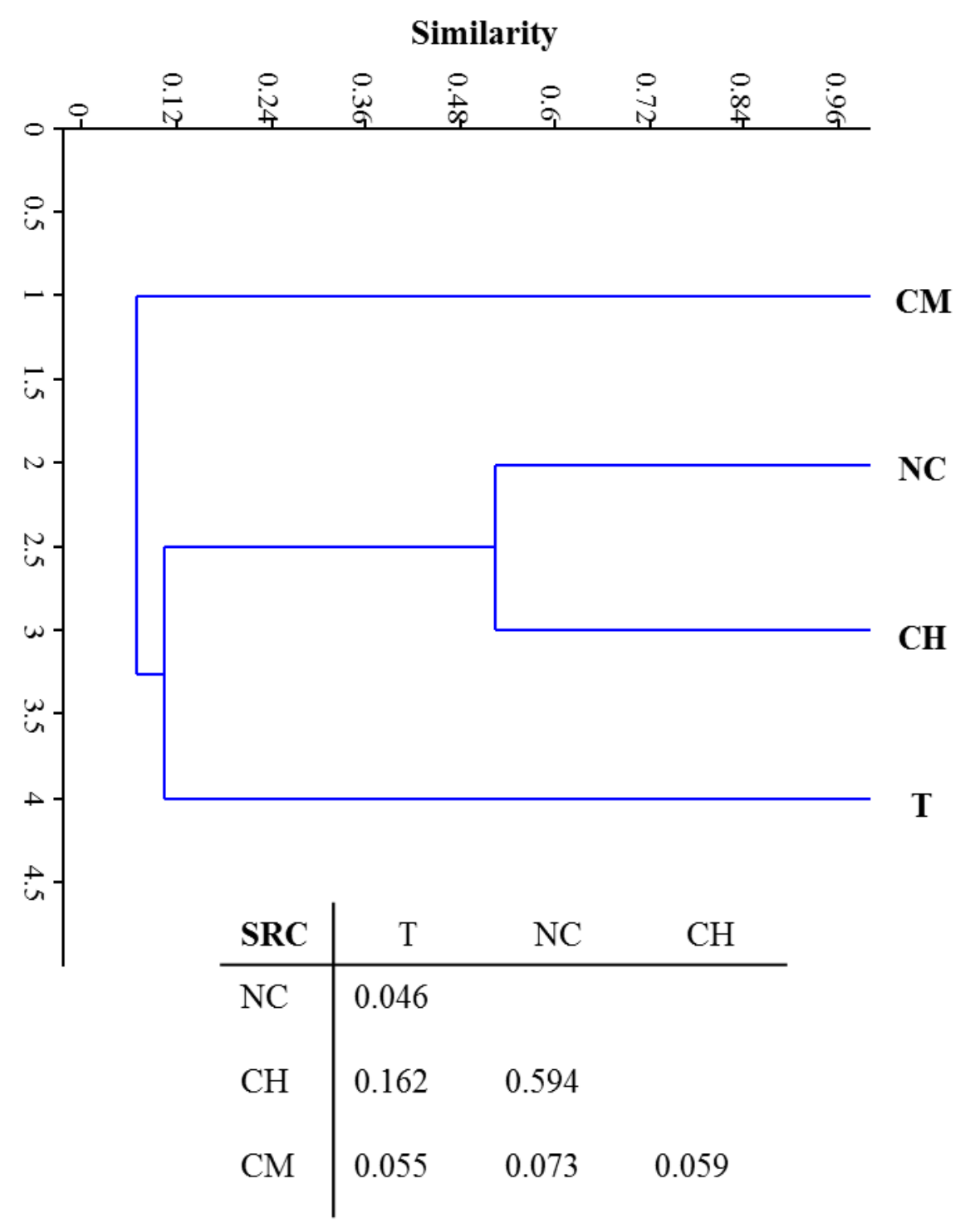

b)

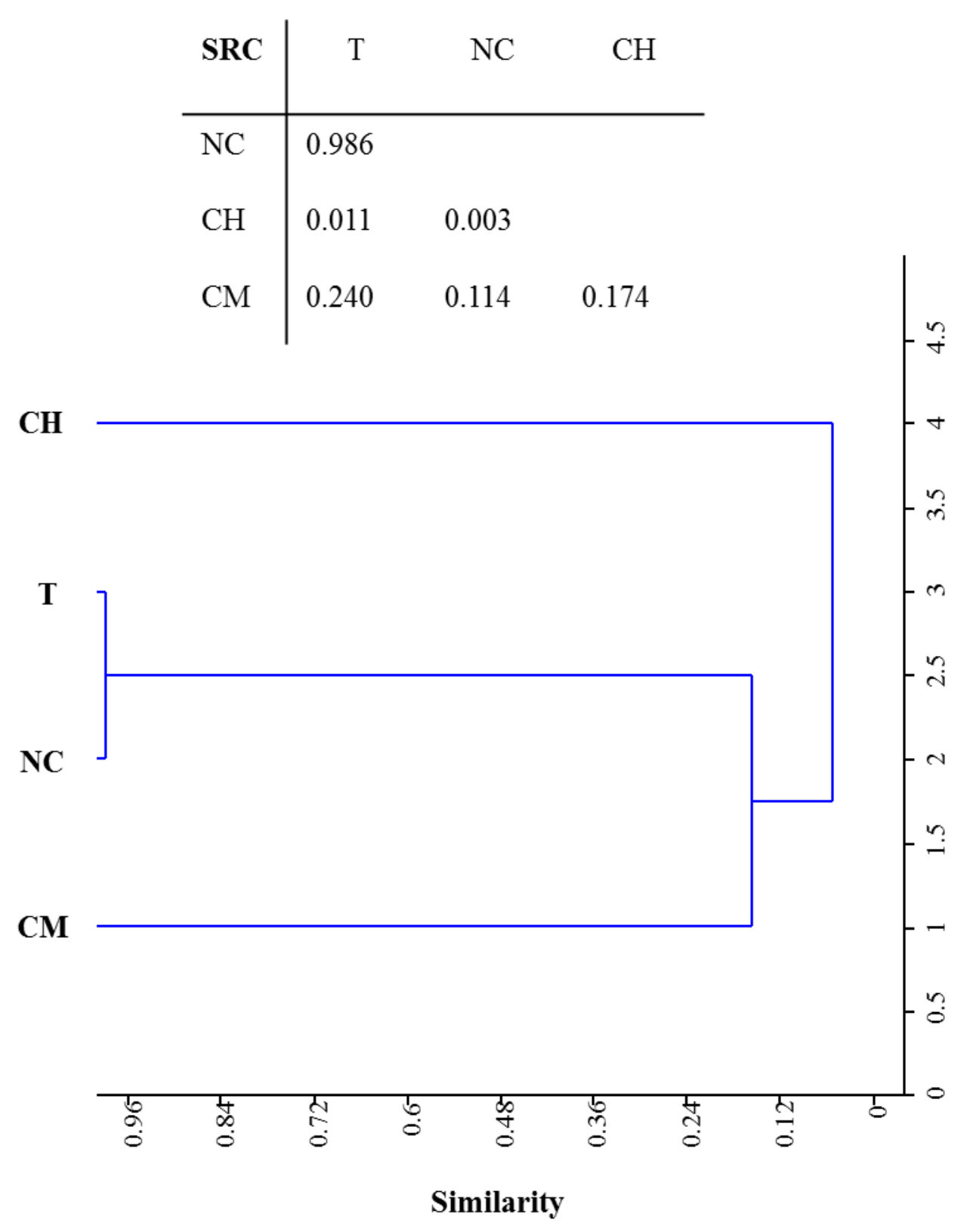

